\title{
Understanding China's Fintech Sector: Development, Impacts and Risks
}

\author{
Xiuping Hua, Yiping Huang
}

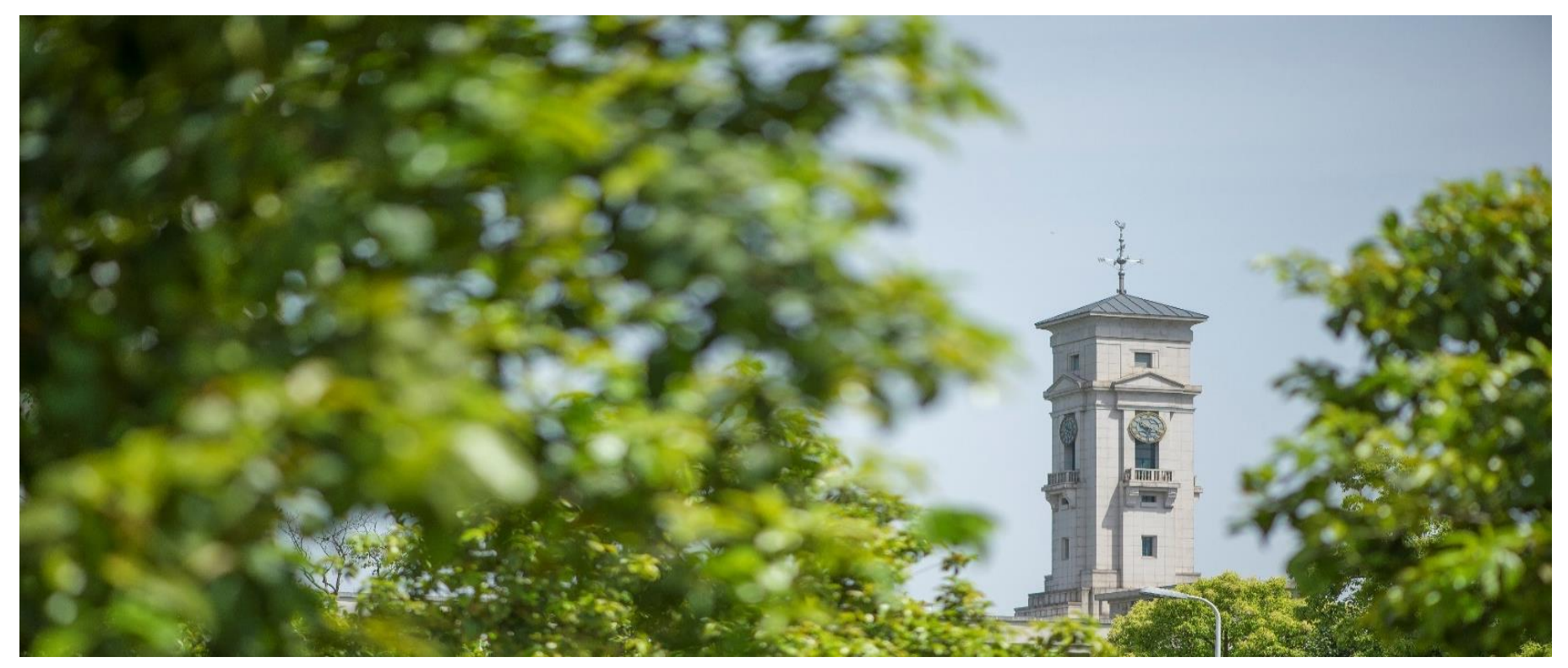


Faculty of Business, University of Nottingham Ningbo China, 199 Taikang East Road, Ningbo, 315100, Zhejiang, China.

First published 2020

This work is made available under the terms of the Creative Commons Attribution 4.0 International License:

http://creativecommons.org/licenses/by/4.0

The work is licenced to the University of Nottingham Ningbo China under the Global University Publication Licence:

https://www.nottingham.edu.cn/en/library/documents/researchsupport/global-university-publications-licence-2.0.pdf 


\title{
Understanding China's Fintech Sector: Development, Impacts and Risks
}

\author{
Xiuping Hua ${ }^{\mathrm{a}}$, Yiping Huang ${ }^{\mathrm{b} *}$
}

${ }^{a}$ Professor in Finance, UNNC-NFTZ Blockchain Laboratory, Centre for Inclusive Finance, University of Nottingham Ningbo China, China.

${ }^{b}$ Corresponding author, Professor of Economics and Finance, National School of Development, and Director, Institute of Digital Finance, Peking University, Beijing, China, 100871; Email: yhuang@nsd.pku.edu.cn 


\section{Understanding China's Fintech Sector: Development, Impacts and Risks}

Financial technology (fintech) is rapidly transforming the economy as well as the financial landscape in China. This paper attempts to shed light on its contributing factors, current state, economic impacts and potential risks. We identify three key drivers for China's fintech development, namely shortage of supply in formal financial market, strong government support for promoting financial inclusion through digital technology, and more "tolerant" regulatory environment. The greatest value of the Chinese fintech sector is promotion of financial inclusion, enabling a vast number of small- and medium-sized enterprises (SMEs) and low-income households to access to financial services. Existing studies unveil some strong evidences of fintech development improving efficiency, increasing employment and supporting entrepreneurship. In the meantime, there are also serious challenges facing this sector, such as regulatory uncertainties, illegal transactions, data abuse, etc. We conclude the paper by presenting some key takeaways, including several lessons for financial regulation.

Keywords: Financial technology; financial inclusion; financial stability; China

JEL classifications: G20; G29; O16 


\section{Introduction}

Financial technology (fintech) is revolutionizing the financial industry at an extraordinary pace (Demirguc-Kunt et al. 2018; Gomber et al. 2018; Goldstein et al. 2019; Hua et al. 2019). With the help of digital technology, many changes, most of which were unthinkable even a decade ago, are taking place at unprecedented scale, in almost all aspects of the financial industry in China (Chen 2016; Xiao et al. 2017). For instances, each of the two leading mobile payment service providers, Alipay and WeChat Pay, has around 1 billion active users (Klein 2019). Many of these users organize their daily lives around the digital payment-centred ecosystems, from making doctor appointments to purchasing air-tickets, and from paying electricity bills to investing in financial products. By 2019, each of the three virtual banks, WeBank, MyBank and XWBank, employing between 1,000 and 2,000 staff, had been extending around 10 million individual or small- and medium-sized enterprise (SME) loans annually. ${ }^{1}$ This development, especially its promotion of financial inclusion, has attracted broad international attention (see, for instances, Frost et al. 2019, and Klein 2019).

In many ways, China's fintech sector looks different from those in many developed countries. One, in North America and Western Europe, much attention in the fintech space is placed on crypto currencies and cross-border payment while, in China, most of the headline news covers mobile payment, online lending and online investment. Two, China's fintech landscape is dominated by a small number of unicorn players such as Ant Financial, Tencent, Baidu and JD Digits. ${ }^{2}$ In North America and Western Europe, the fintech sector is overwhelmed by a large

\footnotetext{
${ }^{1}$ This information was obtained through authors' direct communication senior executives of these three online banks.

${ }^{2}$ Ant Financial Services Group is affiliated with the e-commerce giant Alibaba, owns Alipay and is also a sponsor of the MyBank. Tencent started business in online games, but it is widely known for its social media service WeChat, on which it also built WeChat Pay and sponsored the WeBank. Baidu specializes in search engine in Chinese texts, owns a financial arm, Duxiaoman, and also formed a joint venture bank, Baixin Bank, with Citic Bank. JD Digits is affiliated with the e-commerce giant JD and owns numerous financial licenses.
} 
number of small companies. Three, perhaps the most distinctive feature of China's fintech development is "financial inclusion" - it improves access to financial services at scales never seen before in human history (Huang and Huang 2018; Chong et al. 2019; Zhang and Chen 2019). And, four, unlike many of their developed country counterparts, most Chinese fintech companies often own multiple financial service licenses and directly offer financial products to customers.

China's fintech sector also has evolved dramatically over time. It started in December 2004 when Alipay first came online, but the real boom did not begin until June 2013, when Ant Financial successfully launched its online money market fund Yu'ebao (Huang and Huang 2018; Zhang and Chen 2019). From 2014, the Government Work Report, which is delivered by the Premier at the annual National People's Congress meeting, started to mention "internet finance" (the Chinese term for fintech) almost every year, ${ }^{3}$ but the tune gradually shifted from praising for innovation to warning about the risks. The rise and fall of the online peer-to-peer (P2P) lending industry, which once had more than 6 thousand platforms at its peak in 2015, offers a case in point (Wang et al. 2016).

While China's fintech sector has achieved a great deal in improving financial efficiency and promoting financial inclusion, it has also created uncertainties, financial risks and even social problems. First, the sector as a whole is still in its early stage of development and many of the business models are not yet mature. Some newly invented risk assessment methods, for instance, still need to be tested throughout the complete financial cycles. We are yet to fully understand the implications of fintech for formation and transmission of financial risks. Second, many fintech firms analyse whatever "big data" they are able to put their hands on. This often yields useful results but, at times, also causes serious problems such as information monopoly and insufficient

\footnotetext{
${ }^{3}$ In the Chinese context, the terms "internet finance", "fintech" and "digital finance" all have similar meanings, though the official documents normally use "internet finance".
} 
protection of privacy (Luohan Academy Report 2019). And, finally, the authorities are still in the process of developing proper regulatory frameworks for a number of fintech businesses. This could potentially bring about significant shocks to the fintech sector. For instance, the P2P industry in China started in 2007 and remained unregulated for nine years. When the authorities adopted the new regulatory policy for P2Ps in 2016, the industry nearly collapsed and became a major source of financial and social risks.

The purpose of this paper is to provide a comprehensive review of China's fintech evolution - its contributing factors, development process, economic impacts and potential risks. By summarizing the existing studies, documenting the actual trajectory and drawing important implications, this paper attempts to contribute to a better understanding of China's fintech sector. Specifically, we hope to add to the existing literature in the following three aspects. Firstly, we attempt to rationalise rapid development of China's fintech sector and its unique focus on financial inclusion. Secondly, we quantitatively describe current state of the fintech sector and its development trajectory. And, thirdly, we examine economic and financial impacts of fintech development on the Chinese economy by mainly reviewing the existing literature. On top of these, we also try to draw some lessons for financial regulation.

The remainder of the paper is structured as follows. In the next section, we analyse the unique institutional background and the key contributors to development of China's fintech sector. In the third section, we describe development of this sector by employing some unique quantitative indices and other information. In the fourth section, we assess the economic impacts caused by the fintech sector. And, in the final section, we conclude the paper by drawing some lessons for financial regulation.

\section{The institutional background and key contributing factors}


Almost all fintech businesses in China were spontaneously created by the private sector. But, in one way or the other, they were also closely linked to China's unique institutional background and government policies. Repressive financial policies left a large portion of customers unserved by the formal financial industry, which created huge space for the fintech sector to grow. The government's massive spending in infrastructure, especially on information and communications networks, boosted wide adoption of digital technology. And the regulators' more "friendly" attitude toward fintech businesses further encouraged innovation in this area. In summary, we attribute development of China's fintech sector to three key factors: supply shortage in the formal financial market, strong government support for promoting financial inclusion through digital technologies, and relatively accommodative regulatory environment.

The first contributing factor was the highly repressive financial policy. The Chinese government maintained widespread and heavy interventions in the financial system, such as regulated interest rates, state-influenced credit allocation and tightly controlled capital account, throughout the entire reform period (Huang and Wang 2011). China's financial repression index (FRI) declined from 1.0 in 1980 to 0.6 in 2015 (Figure 1). ${ }^{4}$ These certainly imply that the Chinese financial system was moving toward a free market system but the pace of this transition was much slower than other transitional economies. For instance, Russia started its economic reform about 10 years after China. But in 2015, its FRI was already 0.4, indicating a much faster pace of financial liberalization than China. In fact, in 2015, China's FRI stilled ranked the 14th out of 130 economies and was even higher than the average level of low-income countries (Huang and Ge, 2019).

(Insert Figure 1 here)

\footnotetext{
${ }^{4}$ According to definition of FRI, 1 indicates completely state-controlled and 0 indicates completely free market (Huang and Wang 2011).
} 
This repressed financial system discriminates against SMEs and low-income households in their access to financial services. For instance, in 2008, only about 20 percent of Chinese SMEs had ever received bank loans and the credit card penetration rate was only around 19 percent. Underservice of SMEs and lowincome households probably explained why informal financial activities have been active in China (Ayyagari et al. 2010). Allen et al. (2005) find that the fastest-growing Chinese firms mainly rely on informal financing channels. Many fintech businesses grew rapidly for exactly the same reason (Hau et al. 2019). Like typical informal financial activities, many fintech businesses, at least in their early days, were not properly regulated and focused on SMEs and low-income households. When fintech sector started to offer online payment, lending and even investment services, it was enthusiastically embraced by the market because it fills some important gaps. This also explains why, compared to the fintech sectors in many developed world, the Chinese fintech businesses are more inclusive in nature (Demirguc-Kunt et al. 2018; World Bank 2019).

The second contributing factor was a strong government push towards promoting financial inclusion by the rapid adoption of digital technologies, such as artificial intelligence, big data and cloud computing, and the development of good physical infrastructure like telecommunications, the internet and smart phones. In emerging economies like China, financial consumers had few or no other alternatives to digitalized financial services before the 21st century (Luohan Academy Report 2019). Nevertheless, the Chinese government learned from international experiences that digital technologies are capable of promoting inclusive economic growth and proffering better financial solutions with more efficiency and higher accessibility to all of society.

Rapid development of digital technological capability was a result of combined efforts by both the government and the private sector. In China, the government has made massive investment in infrastructure, especially information and communications infrastructure across the country. Such infrastructure enabled individuals and enterprises to connect to the bigtech platforms from almost anywhere in the country. This is particularly valuable for people living in remote areas where formal financial services are often scarce. 
The business sector also made its own contribution. China now has a considerable number of manufacturers of digital technological equipment, especially smart phones, with good quality but reasonable prices. In 2011, Alipay could handle only about 300 transactions per second. This number reached well above 300,000 in 2019 (Authors' interview). New financial solutions that are built on fintech, spanning from mobile or internet payments to P2P applications, are seen to be able to fill the financial inclusion gaps in emerging economies, such as the gender gap, gap between the rich and poor, and so on (Demirguc-Kunt et al. 2018; World Bank 2019).

And the third contributing factor was the relatively accommodative regulatory environment. In fact, for quite a while, regulation was absent for many fintech businesses. Alipay started business at the end of 2004 but did not obtain an official license until 2011. The first P2P platform, FinVolution Group, came online in 2007 and the P2P industry grew at an extraordinary pace in the following years. Nevertheless, regulators did not set regulatory standards until mid-2016. There were probably two reasons regulators did not rush to bring these businesses under regulation. On the one hand, many government officials saw the value of financial inclusion in fintech businesses and so they were reluctant to disrupt such "financial innovation". And, on the other hand, China's financial regulatory framework is one segregated by industry and focuses on financial institutions. The working rule of this system is "whoever issue the license should be responsible for regulation". In a way, fintech companies fell into the gap area, to which no specific regulator was responsible.

Regulatory "tolerance" is a double-edged sword. It allowed the fintech players to freely experiment with new business models and financial products. But, at the same time, it also gave rise to some improper practices and even Ponzi schemes. Here, again, experiences of the P2P industry offers a useful example. During the first nine years, P2P platform operators adopted all sorts of practices to grow and sustain their businesses, including auto bidding, fund pooling and guarantees (Wang et al. 2016; Peng 2014). When the rules were announced in mid-2016, which requires P2P platforms to operate strictly as information intermediaries, most operators found themselves unable to comply with the new standards. In hindsight, 
the chaos in this industry during the past several years might have been avoidable should the regulators set clear standards from the very start.

\section{Current state of China's fintech sector}

Fintech development is a global phenomenon and China is leading in many areas. Taking mobile payment as an example, people are using this new service worldwide, but breadth and depth of the Chinese service clearly stand out. As Global Findex Database shows, in 2014, only 44 percent of Chinese adults used digital payment, while, in 2017, this number rose to $68 \%$ (Figure 2). This number must be even higher today, because both Alipay and WeChat Pay launched the Quick Response (QR) code to include offline businesses in their mobile payment networks.

(Insert Figure 2 here)

In order to proffer a bird's-eye view of China's fintech sector, we first introduce the Peking University Digital Financial Inclusion Index of China (DFIIC) (Guo et al, 2019). DFIIC is developed by Peking University's Institute of Digital Finance in collaboration with Ant Financial and annually quantifies China's fintech businesses at national, provincial, municipal and county levels as well as for different businesses including mobile payment, online lending, digital insurance, online investment and other digital financial services. A close look at the index reveals at least two important findings. One is extraordinary pace of growth. The median of provincial indices was 33.6 in 2011 but rose to 294.3 in 2018, implying an average growth rate of 36.4 percent (Figure 3). As a comparison, based on our calculation, the newly increased total social financing of the formal financial sector, rose from RMB12.8 trillion to RMB19.3 trillion during the same period, growing only by 6 percent a year.

(Insert Figure 3 here) 
And the other is rapid convergence. The highest-lowest provincial index ratio dropped from 50.4 in 2011 to 1.4 in 2018 . The municipality-level data also showed significant convergence across the country during those years (Figure 4). On two maps in Figure 4, each municipality is coloured according to its DFIIC reading. In 2011, with the exception of the southeast coastal region, the rest of the country was largely underdeveloped. In 2018, however, the crossmunicipality gaps narrowed sharply. This implies that during 2011-2018, the lagging municipalities were rapidly catching up with the leading ones. Again, this is very strong evidence of financial inclusion. In 1935, Chinese economics geographer HU Huanyong drew a line on China's map from Heihe in Heilongjiang to Tengchong in Yunnan, which is later known as the HU Huanyong Line (Hu 1935). ${ }^{5}$ On the right side of this line, about 46 percent of total land area supported 96 percent of the population. In recent years, however, with the help of digital technology, fintech sector crossed the Hu Huanyong Line for the first time and moved rapidly into the western region of the country.

\section{(Insert Figure 4 here)}

At the disaggregated level, fintech development have been more successful in mobile payment, online lending, digital insurance, and online investment. The past years witnessed rapid expansion of China's mobile payment business, in terms of not only active users but also transactions. The number of active users of Alipay increased from a little over 100 million in 2013 to 900 million in 2018, while that of WeChat Pay grew from about 350 million to 1.1 billion during the same period. The total transaction value jumped from RMB14.5 trillion in 2013 to RMB277.4 trillion in 2018, recording an annual growth rate of 80 percent (Figure 5). The share of mobile payment in total non-cash payment value rose from less than 1 percent in 2013 to 7.4 percent in

\footnotetext{
${ }^{5}$ HU Huanyong elaborated first presented the idea of this HU Huanyong Line in the journal article "Distribution of China's population" in Journal of Geographical Sciences (in Chinese) in 1935.
} 
2018 , and the share of mobile payment in total number of non-cash payment transactions increased from 3.3 percent in 2013 to 27.3 percent in 2018. In fact, in China, mobile payment service has leapfrogged paper checks and plastic cards in advanced economies and has become the most popular payment tool in the country.

\section{(Insert Figure 5 here)}

Mobile payment may be regarded as the core business of China's fintech sector, as it sets up the bigtech platforms, links to hundreds of millions of users and records gigantic volumes of digital footprints. Although Alipay and WeChat Pay started from very different origins, the logics of their fintech development are remarkable similar. Once the platforms are set up, the operators could gradually build ecosystems around the payment service. Therefore, mobile payment service users could start to enjoy other services on the same platforms using the same accounts: online shopping, ordering delivery, buying tickets, making investment, etc.

One Chinese fintech business that stands out alongside mobile payment is online lending, which opens a new door to inclusive lending. Here we refer to lending by virtual banks, not by P2P platforms. The main obstacles for commercial banks to lend to SMEs and low-income households are customer acquisition and risk assessment. Since these potential customers are small in size and scattered in location, it is difficult and costly to locate them and figure out their financial needs. In addition, commercial banks often make credit risk assessment using either historical finance data or fixed assets as collaterals, which most SMEs and low-income households do not have. The mobile payment services help solve the first problem - with around one billion users on each platform, customer acquisition is no longer a high hurdle.

At the same time, the virtual banks have created their own credit risk assessment models. WeBank started with social media WeChat data and then added WeChat Pay information, while 
MyBank started with e-commerce information and also utilized Alipay data. XWBank established an open online banking system to connect with other existing platforms. A close look at the fintech approach of credit risk assessment using big data and machine learning model, in comparison with the bank approach relying on traditional data and scorecard model, reveals some striking features. One, replacing traditional data with big data or replaying the scorecard model with the machine learning model can significantly improve performance of risk assessment. Two, the most important advantage of the fintech approach, however, is that it is able to cover a very large portion of the customers, who have never served by commercial banks. This is what we mean by inclusive lending. And, three, even when faced with exogenous policy shocks, the relative outperformance of the fintech approach is sustained, if not enhanced, after such shocks (Gambacorta et al. 2019).

The fintech approach works better than the bank approach for at least two reasons. The first is information advantage. The bank approach relies mainly on financial data, which are accurate and reliable but also easily outdated. In contrast, the fintech approach relies more on real time data from bigtech platforms. It also uses behaviour data, most of which are proprietary information from bigtech platforms. The behaviour data are often more stable even during shocks. And the second is model advantage. The scorecard model is a linear method. The machine learning model can better capture not only non-linear relations but also interactions among different explanatory variables. In summary, the fintech approach can effectively reduce the degree of information asymmetry to control the adverse selection problem, i.e., distinguishing "good" borrowers from "bad borrowers". Real time monitoring could also help reduce the moral hazard problem. In addition, since the borrowers are all parts of the "ecosystems", bigtech companies can create some kinds of leverage, such as downgrading rating of an online shop, to prevent the borrowers' bad behaviour. 
MyBank created the so-called " 310 model" of online lending - it takes the customer 3 minutes to apply; the approved loan amount is in the borrower's account within 1 second; and there is no human interference in this whole process. The processes adopted by WeBank and XWBank are very similar. This way, they are able to offer millions of online contactless loans to SMEs and low-income households and, at the same, keep the non-performing loan ratios at 1-2 percent.

Online lending by the Chinese virtual banks is a financial revolution, especially in terms of financial inclusion. This experience should be extendable to other institutions in China and other countries. But it is also important to point out that the barrier for conducting this business is also quite high. China's failing P2P industry offers an example in the opposite direction. In short, financial institutions might be able to replicate what the three Chinese virtual banks are doing if they have access to big data and have the analytical capability. Recently, some major Chinese banks start to make massive investment in setting up their own tech platforms. These banks have enough resources, skills and customers. Whether or not they will be successful depends critically on their ability to build the "big data" - continuous, wide range digital footprints. For most other banks, it might be easier for them to cooperate with fintech companies, including the virtual banks. This is also the direction that Chinese banking regulators are encouraging. ${ }^{6}$

\section{Economic impacts of fintech development}

\section{a) Positive impact on the economy and financial inclusion}

While documenting China's fintech development process is important, it is equally useful to examine the likely changes it brought about to the economy. The list of academic studies in this

\footnotetext{
${ }^{6}$ Notice for public consultation "On temporary management methods for commercial banks' online lending". http://www.moj.gov.cn/government_public/content/2020-05/09/657_3248297.html (Chinese government's official website).
} 
area is still relatively short but growing (Chen et al. 2019). And there are already some fascinate evidences of the effects on financial inclusion, economic efficiency, innovation and entrepreneurship.

First, the fintech sector makes financial service more inclusive and more efficient. Delivering responsible and sustainable financial services to SMEs and low-income households is a global challenge (Nanda and Kaur 2016). But with help of digital technology, hundreds of millions of users, especially SMEs and low-income households are able to make mobile payment, apply for online loans, purchase digital insurance products and make online investment products. These are made possible by digitally lowering hurdles for both customer acquisition and risk assessment in the fintech sector (Xie et al. 2016). It also pushes the "frontier" of credit availability to firms with low credit worthiness by significantly improving risk control methods (Hau et al. 2018). Leong et al. (2017) explore the development of a fintech company in China that offers microloans to college students and argue that fintech is capable of proffering a strategic advantage for firms to occupy this niche in China's financial market. They suggest that it is possible to analyse customers' digital footprints to construct a non-traditional, alternative and substantive source of data in generating new credit scores. Similarly, Frost et al. (2019) find that fintech lenders have an information advantage in credit assessment relative to a traditional credit bureau. Fintech companies are capable of exploiting their existing trading networks and massive amounts of data generated by existing business lines such as e-commerce or social media services, though they cannot access traditional soft information in a way that human loan officers in traditional banks are able to collect. Hau et al. (2019) also emphasize that fintech credit providers like Ant Financial and WeBank enjoy a competitive advantage over traditional commercial banks because of their 
more powerful credit technologies and cheaper distribution channels, as well as comparative information advantages.

Second, fintech application creates value by promoting technological innovation and entrepreneurship. Xie et al. (2018) employ PKU-DFIIC (Stage I, 2011-2015) and find that China's fintech sector has significantly promoted innovation and entrepreneurship. Based on computerized credit lines to more than one million firms that conduct business on the e-commerce platform Taobao, Hau et al. (2018) discover that Fintech credit access boosts a vendor's sales and transactions, and this positive impact is even larger for younger firms and younger entrepreneurs. Chong et al. (2019) analyse five fintech companies in mainland China that have rolled out blockchain initiatives and explore the potential value creation logics and mechanisms of blockchain related businesses. Frost et al. (2019) confirm that Chinese firms that accessed the Fintech credit market were able to expand their product offerings more than those that did not. Wang (2019) examines the impacts of mobile payment on farm households by applying both DFIIC and household survey data. She discovers that adoption of mobile payment would significantly increase a farmer's probability of becoming an informal business owner in the following period and would also markedly raise their income. An and Rau (2020), Momtaz (2020) and Zhao et al. (2020) emphasize the innovativeness of incorporating blockchain and smart contracts in fundraising of projects yet to be developed through technology advances such as ICOs.

And, finally, China's fintech plays an irreplaceable role in creating business opportunities, improving social equality, helping eliminate poverty, and lessening income disparity, particularly in less developed parts of China (Xie et al. 2016; Guo et al. 2019). Hau et al. (2019) summarize that the regions with less credit supply from traditional banks, higher shares of SOEs due to their monopoly in traditional bank credit, and rural areas with less concentrated local bank branches 
benefit from Fintech services the most. In other words, fintech lays a foundation for low-income and disadvantaged groups to have access to low-cost financial services and is thus an important source to realize lower-cost, wider-coverage and more sustainable financial inclusion. Aisaiti et al. (2019) investigate China's rural farmers' financing in the context of fintech, and find that fintech, as a modifying factor, is able to significantly strengthen the positive correlation between perceived benefits of ordering finance and financing intention of inclusive financial services in rural China.

By combining a randomized control trial with a new survey and administrative microdata, Couture et al. (2020) show how fintech influences consumer welfare, with a specific focus on rural households in China during 2014-2018. They find that overall, access to e-commerce appears to offer economic gains to certain groups of the rural population and in certain places. In particular, rural households experience a reduction in living costs due to online purchases, especially for durable spending and for remote rural residents. To summarise, based on the experience from the last decade, China's Fintech advancements make it possible for economically undeveloped regions to catch up with and even surpass other regions (Guo et al. 2019). The fintech development has especially strong positive impacts on financial inclusion of rural areas.

\section{b) Negative impacts and evolving risks}

However, the changes brought about by fintech development to the Chinese economy are not all positive. A number of papers show that financial innovations and fintech development are capable of generating negative impacts on social wellbeing (Karlan et al. 2016). Health of the Chinese fintech sector, including reliability of some of the fintech business models, increasingly became a serious concern in recent years (Frost et al. 2019; Zetzsche et al. 2017). Most of these risks are related, in one way or the other, to regulation in the new digital age. 
While relative slow to come up with regulatory framework for most fintech businesses, the Chinese authorities were quick in restricting and even prohibiting trading of crypto currencies and issuance of the initial currency offerings (ICOs) (Zhao et al. 2020). Regulators had at least two main concerns. One is that crypto currencies and ICOs could potentially make many laws and regulations ineffective. This is particularly so for anti-money laundering regulations and crossborder capital flow management. And the other is the fact that these transactions could easily become fraudulent because of investors' lack of knowledge and also lack of effective monitoring and supervision mechanisms. So the authorities' decisions to ban such transactions were justifiable. The only problem is that such transactions could be moved offshore, with many Chinese citizens continuing to participate actively. Such kind of regulatory arbitrage could cause some potential risks for China, although the exact type and magnitude of such risks are not yet clear. In addition, the announcement by Facebook of the plan to launch the stable currency Libra suggests that the outright ban of crypto currency trading could also have unexpected consequences (The Libra Association 2019). In the meantime, the People's Bank of China (PBoC) is accelerating its steps of launching its own central bank digital currency - digital currency/electronic payment (DC/EP). All these suggest that China will probably need to think through all these digital currency-related issues and come up with a comprehensive policy framework, which hopefully would control the risks and at the same time allow Chinese institutions to participate in this international competition.

China's P2P lending is another typical fintech sector facing market crash challenges due to regulatory disruptions. It was created to allow consumers to request small loans online and creditors to evaluate and directly choose the loans they are willing to fund, but many P2P firms have evolved to take determinant roles in lending decisions and become new intermediaries, which 
makes the market vulnerable to moral hazards (Balyuk and Davydenko 2019). The early Chinese P2P platforms, like its counterparts in United States and United Kingdom, were initially set up as information intermediaries. However, since the platforms could not access the central bank's credit scoring system and could not engage in risk intermediation, it was impossible for the lenders to evaluate and control adverse selection and moral hazard problems (Wang et al. 2016). Because of absence of rigid regulation, the number of $\mathrm{P} 2 \mathrm{P}$ platforms reached more than 6000 , while the total outstanding loan in the peak year, 2017, was RMB1.2 trillion. At the end of 2015, collapse of one P2P platform, Yi'zu'bao, involved almost one million investors. This points to potential risks that fintech development could bring about to the financial system, economy and society. Financial problems are common in informal lending area. The main difference of the $\mathrm{P} 2 \mathrm{P}$ industry is that it utilizes digital technology - participants are much bigger in numbers and more scattered in geographical location. Therefore, transmission of risks could be faster and broader. One of the main problems of the $\mathrm{P} 2 \mathrm{P}$ industry was lack of regulation.

After the regulators announced the regulatory framework in August 2016 and required the P2Ps to function purely as information intermediaries, the number of operating platforms has declined sharply. At the end of 2018, it came down to 1012, and the actual number has dropped much further in 2019. The collapse of P2Ps was unfortunate and the social impact was devastating, as the sector involved a very large number of investors. In many Chinese cities today, failing P2Ps are a top concern for social stability. Accordingly, public sentiment, measured from news reports, became very volatile during 2017 and 2018 (Figure 6).

(Insert Figure 6 here)

Absence of regulation in the $\mathrm{P} 2 \mathrm{P}$ industry was unfortunate. But it also exists in other fintech areas. Analysts already observe increasing fraudulent fundraising and asset misappropriation 
activities in China's equity crowdfunding (ECF) industry, and find that there are several serious lessons to be learned from this market (Lin 2017).

There are also some more general concerns in this industry. These include increasing threats to privacy, investor protection, information monopoly and access inequality as well (Frost et al. 2019; An and Rau 2020; Zhao et al. 2020). In many fintech business models, data sharing is essential and critical, which makes it very hard to protect privacy. Most individuals lack the clear knowledge of what information fintech firms have about them and may not have a very good idea of how that information is employed and with what impacts. Choosing what to protect and what to reveal is rather difficult in the fintech context, and different social groups have different views about the trade-offs (Luohan Academy Report 2019). Meanwhile, Frost et al. (2019) argue that big fintech firms sometimes result in greater concentration of market shares and are able to further concentrate market power as well as information monopoly. They have the potential to give rise to access inequality as well as new financial systemic risks. An and Rau (2020) point out the dangers in information overload as well as incurring behavioural biases when big data are widely employed by regulators and the public. Zhao et al. (2020) argue that lack of regulation on and discipline in some fintech ventures poses a threat to investor protection and suggest the needs of regulating ICOs.

Finally, the impacts of fintech have been heterogeneous among different households or entrepreneurs. For instance, Banerjee et al. (2019) find that the impacts of access to formal credit through microfinance are highly heterogeneous and such non-convexities contribute to poverty trap dynamics. Those with existing businesses benefit more significantly and persistently in both business and non-business durables spending, but for other entrepreneurs, who are poorer or more reluctant, there is no evidence of impact on their business outcomes or on consumption. Thus, later, 
it is difficult for the latter group of people to rely on new technologies to escape the poverty trap. Even worse, poor fintech business design and abundant regulatory arbitrage are capable of accumulating risks and generating negative impacts on the real economy.

\section{Lessons for regulation and concluding remarks}

China already made significant progresses in developing its fintech businesses. In some business areas, it is a global leader. But the potential risks are also growing. As some of the leading fintech players are already so big and their business structure so complex, they could easily make to the country's list of systemically important financial institutions. Yet the existing regulatory system is not compatible with this new reality. The current industry-segregated regulatory regime was formed after 1992, with four core institutions: PBoC, the banking and insurance regulator, the security regulator and the local financial regulatory bureaus. Each regulator is responsible for regulating a set of financial institutions, coordinated by the State Council Financial Stability and Development Commission. This system needs to be reconfigured to manage financial stability in the digital era. We can draw four lessons for financial regulation from experiences of China's fintech development.

The first lesson is that all financial transactions need to be regulated. The industrysegregated approach of regulation often leaves out many financial activities that do not fall into the traditional categories of financial institutions. Shadow banking and fintech were very important new financial activities in China but were un-regulated or under-regulated. Financial activities need to be closely regulated because financial risks often change quickly, with economy-wide amplifying consequences. This would probably require regulators to change their institutionfocused approach to institution- and function-focused approach. Anyone that would want to engage in financial services should have the necessary qualifications and apply for a license.

The second lesson is that a new regulatory framework needs to be devised to adapt to the de facto universal banking business model. All the leading fintech players in China, Ant Financial, 
JD Digits, Baidu and Tencent, own multiple financial service licenses. This does not necessarily mean China should combine all the financial regulators. For instance, the United States adopts a segregated regulatory system while the United Kingdom adopts the central bank-centred framework. But they are both able to monitor and regulate cross-industry fund flows and risk transmission. In the case of China, an urgent task is to improve the coordination of regulatory policies.

The third lesson is that regulators also need to use innovative policy tools to monitor and regulate financial risks. With fintech, especially bigtech platforms, the speed and breadth of risks spreading are unprecedented. Routine reports by financial institutions, or onsite/offsite inspections, are not sufficient to capture the problems. Regulators also need to apply digital technologies to improve their regulatory capability. Regulatory technology (regtech) should be able to benefit regulators in many ways (Sheridan 2017). Zhu and Zhou (2016) reveal that digital technologies such as blockchain help solve the problems of regulatory compliance and security of fund management by developing a distributed voting system for crowdfunders. Beijing local financial regulatory bureau also created a "smoke index", which monitors the risks of P2Ps in real time.

And the final lesson is that regulators should balance between innovation and stability, including adoption regulatory sandbox practices. Good innovations could bring huge benefits, while bad innovations could cause immense damage. But it is not always immediately clear if an innovation proposal is good or bad. One of the practices adopted by regulators in other countries is a so-called sandbox. A regulatory sandbox is an experimentation space that allows a firm to make their advice platform available to a limited number of financial consumers, and by reducing time and cost, as well as enabling greater access to finance for innovators, it helps to deliver more 
effective competition in the interests of consumers (FCA 2015). From the end of 2019, the PBoC started a process of fintech regulatory experiment, an effective Chinese version of sandbox.

We conclude the paper by summarizing some key takeaways and propose some important directions for future research.

Firstly, Chinese fintech development was a revolution of financial inclusion, benefiting from the supply shortage in the traditional financial market, rapid development and adoption of digital technology and a very "tolerant" regulatory system. Mobile payment is a role business model in business, especially for other developing countries. The fintech approach of credit risk assessment is an impressive innovation and may be applied by traditional financial institutions if they could acquire big data and build necessary analytical skills. In the meantime, lack of proper regulation also caused financial and social chaos in some business areas.

Secondly, to maintain its leading role in the global fintech markets and to mitigate the extravagant risks, China needs to provide an appropriate regulatory. It is also very important to transform the current framework of financial regulation to be compatible with the new reality. The authorities not only need to adopt new regulatory tools such as the sandbox, but also need to implement regulation and liberalization simultaneously.

And, thirdly, we believe that new regulatory framework will result in "fintech development 2.0" in China. In short, it means that the division of labour between "fin" and "tech" will become clearer. Many tech companies will focus on the tech parts of the financial transactions, by providing tech solutions for financial institutions. And the financial institutions will focus on financial products and services but can request the services of tech companies when needed. Such division of labour ensures reap of benefits of digital technology and, at the same time, makes sure control of risks. 
Finally, our paper reveals some possibly interesting research gaps. At first, we discovered a distinct lack of research on how to provide primary solutions to the problems inherent in the China's fintech market, such as misuse of private information, financial fraud crimes, money laundering, and so on. Second, there seems to be a lack of research on the most recent evolution of regtech and how it interacts with as well as reshapes China's fintech market. Third, whether regionally diversified cultures and informal institutions play a significant role in adoption of fintech in different parts of China is also a novel research area to explore. Fourth, how the emerging global digital currencies such as Libra compete with state-issued fiat or digital currencies in China is a top research challenge to face. All of these are relevant aspects and directions for future research.

\section{Acknowledgements}

Research for this paper was supported by the National Social Science Foundation of China (No. 18ZDA091 and 19BJY252).

\section{References}

Allen, F., J. Qian, M. Qian. 2005. "Law, Finance, and Economic Growth in China.” Journal of Financial Economics 77(1): 57-116.

Aisaiti, G., L. Liu, J. Xie, and J. Yang. 2019. “An Empirical Analysis of Rural Farmers’ Financing Intention of Inclusive Finance in China: the Moderating Role of Digital Finance and Social Enterprise Embeddedness.” Industrial Management \& Data Systems 119(7):1535-1563.

An, J. and R. Rau. 2020. "Finance, technology and disruption." European Journal of Finance, this issue. 
Ayyagari, M., A. Demirgüç-Kunt, and V. Maksimovic. 2010. "Formal versus Informal Finance: Evidence from China." Review of Financial Studies 23(8): 3048-3097.

Balyuk, T., and S. A. Davydenko. 2019. "Reintermediation in FinTech: Evidence from online lending." Michael J. Brennan Irish Finance Working Paper Series Research Paper Number 18-17.

Banerjee, A., E. Breza, E. Duflo, and C. Kinnan. 2019. “Can Microfinance Unlock a Poverty Trap for Some Entrepreneurs?” NBER Working Paper Number 26346.

Chen, L. 2016. "From Fintech to Finlife: the case of Fintech Development in China." China Economic Journal 9(3): 225-239.

Chen, M. A., Q. Wu, and B. Yang. 2019. "How Valuable Is FinTech Innovation?” Review of Financial Studies 32(5): 2062-2106.

Chong, A., E. Lim., X. Hua, S. Zheng and C. Tan. 2019. "Business on Chain: A Comparative Study of Five Blockchain-inspired Business Models.” Journal of Association for Information Systems 20(10): 247-265.

Couture, V., B. Faber, Y. Gu and L. Liu. 2020. “Connecting the Countryside via E-Commerce: Evidence from China." American Economic Review: Insights, forthcoming.

Demirguc-Kunt, A., L. Klapper, D. Singer, S. Ansar, and J. Hess. 2018. “The Global Findex Database 2017: Measuring Financial Inclusion and the Fintech Revolution." The World Bank. http://documents.worldbank.org/curated/en/332881525873182837/pdf/126033-PUB-PUBLICpubdate-4-19-2018.pdf.

FCA (Financial Conduct Authority). 2015. "Regulatory Sandbox”. Financial Conduct Authority. November.

Frost, J., L. Gambacorta, Y. Huang, H. S. Shin, and P. Zbinden. 2019. "BigTech and the Changing Structure of Financial Intermediation.” BIS Working Paper Number 779.

Gambacorta, L., Y. Huang, H. Qiu, and J. Wang. 2019. "How do machine learning and non- 
traditional data affect credit scoring? Evidence from a Chinese fintech firm.” BIS Working Paper Number 834.

Goldstein, I., W. Jiang, and G. A. Karolyi. 2019. “To FinTech and Beyond.” Review of Financial Studies 32 (5): 1647-1661.

Gomber, P., R. J. Kauffman, C. Parker, and B. W. Weber. 2018. “On the Fintech Revolution: Interpreting the Forces of Innovation, Disruption, and Transformation in Financial Services.” Journal of Management Information Systems 35(1): 220-265.

Guo, F., J. Wang, F. Wang, T. Kong, X. Zhang, and Z. Cheng. 2019. “Measuring Development of China's Digital Financial Inclusion Index.” Chinese Economic Quarterly, forthcoming.

Hu, H. 1935. "Distribution of China's population.” Journal of Geographical Sciences (in Chinese) 2(2): 33-74.

Hau, H., Y. Huang, H. Shan, and Z. Sheng. 2018. "FinTech Credit, Financial Inclusion and Entrepreneurial Growth." University of Geneva Working Paper.

Hau, H., Y. Huang, H. Shan, and Z. Sheng, 2019. "How FinTech Enters China's Credit Market.” AEA Papers and Proceedings 109(5): 60-64.

Hua, X., Y. Huang, and Y. Zheng. 2019. "Current Practices, New Insights, and Emerging Trends of Financial Technologies.” Industrial Management \& Data Systems 117 (7): 1401-1410.

Huang, Y., and T. Ge. 2019. “Assessing China’s Financial Reform: Changing Roles of the Repressive Financial Policies." Cato Journal 30 (1): 65-85.

Huang, Y., and Z. Huang. 2018. “The Development of Digital Finance in China: Present and Future.” China Economic Quarterly 17 (4): 205-218.

Huang, Y., and X. Wang. 2011. "Does Financial Repression Inhibit or Facilitate Economic Growth? A Case Study of Chinese Reform Experience." Oxford Bulletin of Economics and Statistics 73 (6): 833- 
855.

Karlan, D., J. Kendall, R. Mann, R. Pande, T. Suri, and J. Zinman. 2016. "Research and Impacts of Digital Financial Services.” NBER Working Paper 22633. National Bureau of Economic Research, Cambridge, MA.

Klein, A. 2019. Is China's New Payment System the future? The Brookings Institution, Washington DC.

Leong, C., B. Tan, X. Xiao, F. T. C. Tan, Y. Sun. 2017. "Nurturing a FinTech Ecosystem: The Case of a Youth Microloan Start-up in China.” International Journal of Information Management, 37(2): 9297.

Lin, L. 2017. "Managing the Risks of Equity Crowdfunding: Lessons from China.” Journal of Corporate Law Studies 17(2): 327-366.

Luohan Academy Report. 2019. "Digital Technology and Inclusive Growth." Available at: https://gw.alipayobjects.com/os/antfincdn/DbLN6yXw6H/Luohan_AcademyReport_2019_Executive_Summary.pdf

Momtaz, Paul P. 2020. "The Pricing and Performance of Cryptocurrency." The European Journal of Finance, this issue.

Nanda, K., and M. Kaur. 2016. "Financial Inclusion and Human Development: A Cross-country Evidence.” Management and Labour Studies 41 (2): 127-153.

Peng, B. 2014. "Peer-to-Peer Lending and Illegal Financing." Financial Regulation Research 6: 13-25.

PKU-DFIIC. 2019. “The Peking University Digital Financial Inclusion Index of China (2011-2018).” Available at: http://img.bimba.pku.edu.cn/resources/file/15/2019/05/08/20190508105943586.pdf.

Sheridan, I. 2017. "MiFID II in the context of Financial Technology and Regulatory Technology.” Capital Markets Law Journal 12(4): 417-427.

The Libra Association. 2019. Libra White Paper. Available at: http://libra.org/en-us/whitepaper 
Wang, J., Y. Shen, and Y. Huang. 2016. "Evaluating the Regulatory Scheme for Internet Finance in China: The Case of Peer-to-peer Lending." China Economic Journal 9 (3): 272-287.

Wang, J., and Y. Huang. 2018. "Measurement of Fintech Media Sentiment and Its Implications for Online Lending." China Economic Quarterly 17(4): 339-366.

Wang, X. 2019. “Can Mobile Payment Facilitate Entrepreneurial Activity: Evidence from Household Panel Data." China \& World Economy, forthcoming.

World Bank. 2019. "Fintech: The Experience so Far - Executive Summary". World Bank Group. Available at http://documents.worldbank.org/curated/en/130201561082549144/Fintech-The-Experience-soFar-Executive-Summary.

Xiao, X., L. Zhang, Y. Wang and C. Huang. 2017. "China's Path to FinTech Development." European Economy 3 (2): 145-161.

Xie, P., C. Zou, and H. Liu. 2016. "The Fundamentals of Internet Finance and Its Policy Implications in China." China Economic Journal 9 (3): 240-252.

Xie, X., Y. Shen, H. Zhang, and F. Guo. 2018. "Can Digital Finance Promote Entrepreneurship? Evidence from China." China Economic Quarterly 17 (4): 1557-1580.

Zetzsche, D.A., R.P. Buckley, D.W. Arner, and J. N. Barberis. 2017. "From FinTech to TechFin: The Regulatory Challenges of Data-Driven Finance." New York University Journal of Law and Business 14 (2): 393-446.

Zhang, L. and S. Chen. 2019. "China's Digital Economy: Opportunities and Risks." IMF Working Paper Number 2019/16.

Zhao, X. W. Hou, J. An, X. Liu and Y. Zhang 2020. "Initial Coin Offerings: What rights do investors have (if any)?" European Journal of Finance, forthcoming, this issue. 
Zhu, H., and Z. Zhou. 2016. “Analysis and Outlook of Applications of Blockchain Technology to Equity Crowdfunding in China." Financial Innovation 2 (1): 1-11.

Figure 1. Financial Repression Index, 1980, 2000 and 2015

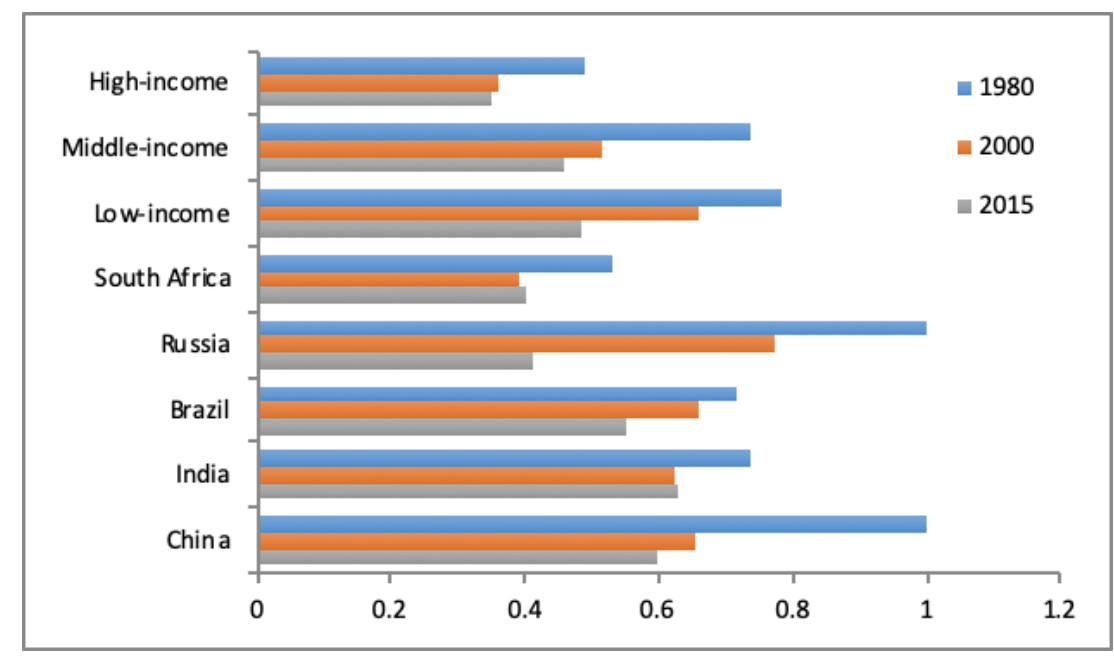

Source: Huang and Ge (2019). 
Figure 2. Adults with an account (\%) are using it for digital payments

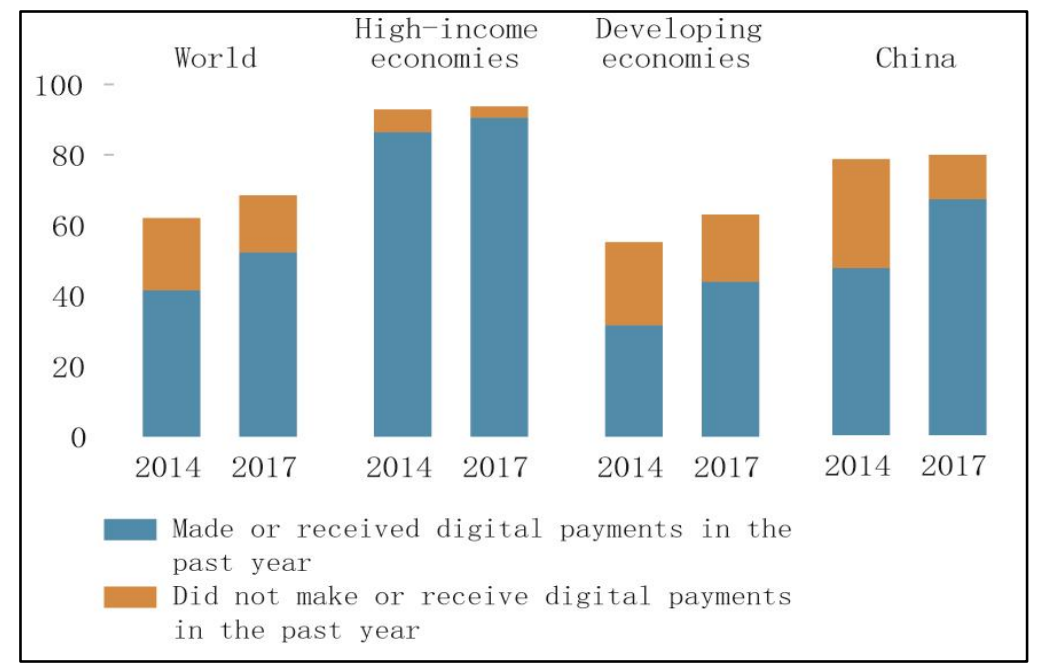

Source: World Bank Global Findex Database 
Figure 3. Provincial means and medians of digital financial inclusion index, 2011-2018

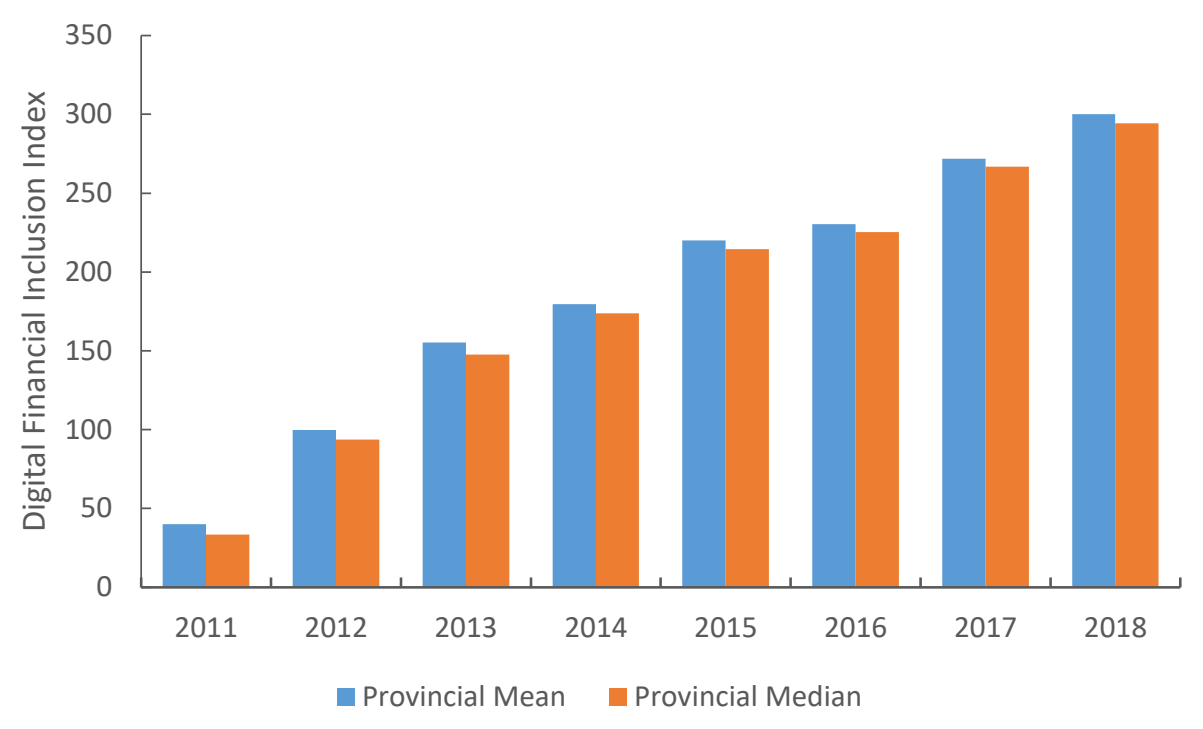

Source: Guo et al. (2019). 
Figure 4. Convergence of regional fintech development in China, 2011 and 2018
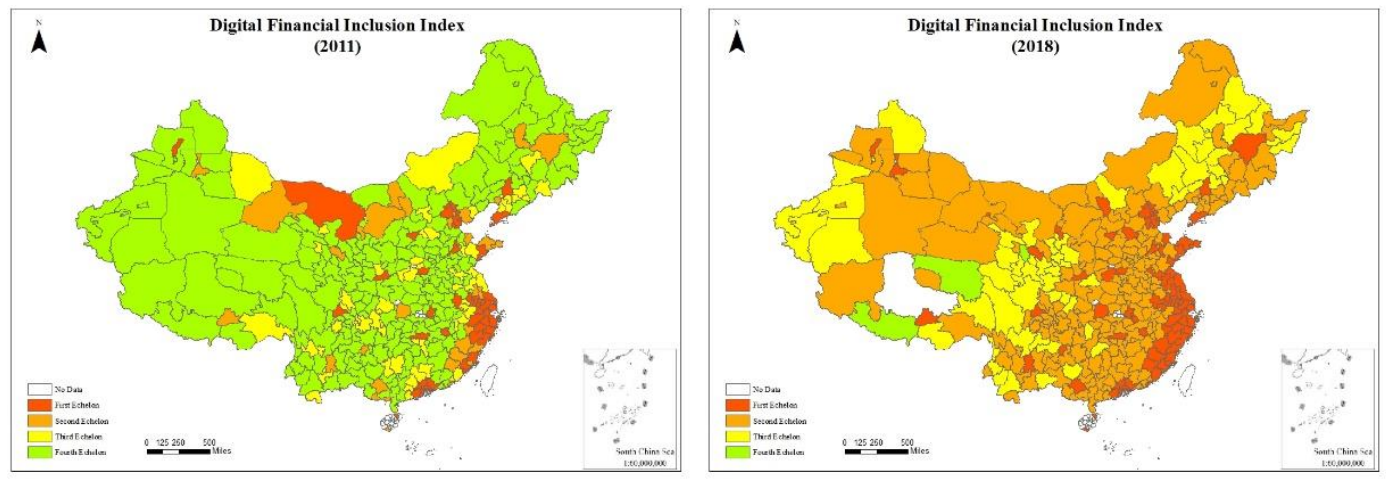

Note: Each year, municipalities are divided into four tiers according to levels of development in that year: tier 1 (red, most advanced), tier 2 (orange), tier 3 (yellow) and tier 4 (green, least developed).

Source: Guo et al. (2019). 
Figure 5. Transaction Value of Mobile Payment in China, 2013-2018 (RMB trillion)

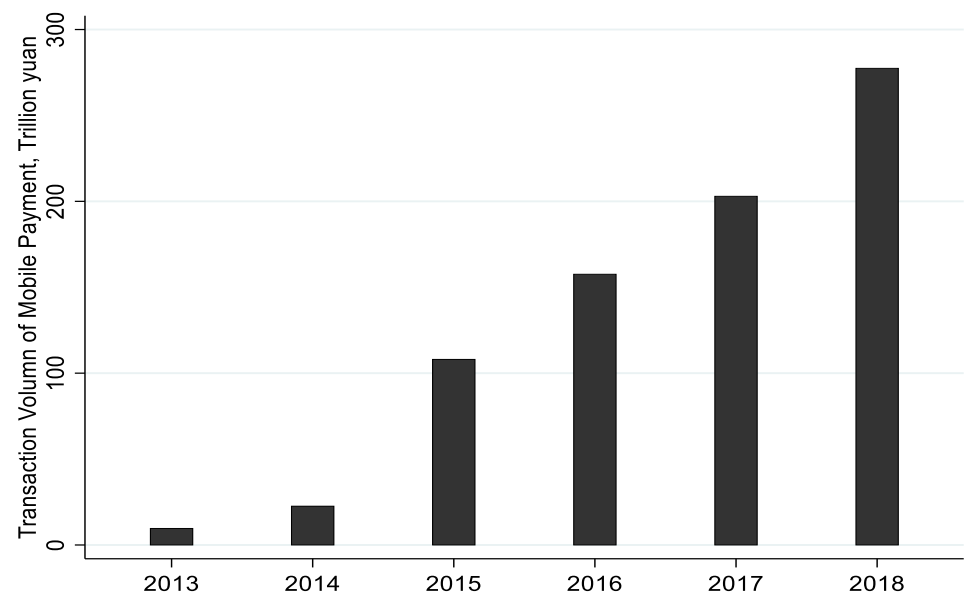

Source: CEIC; PBoC. 
Figure 6. Peking University Fintech News Sentiment Index, 2013-2018

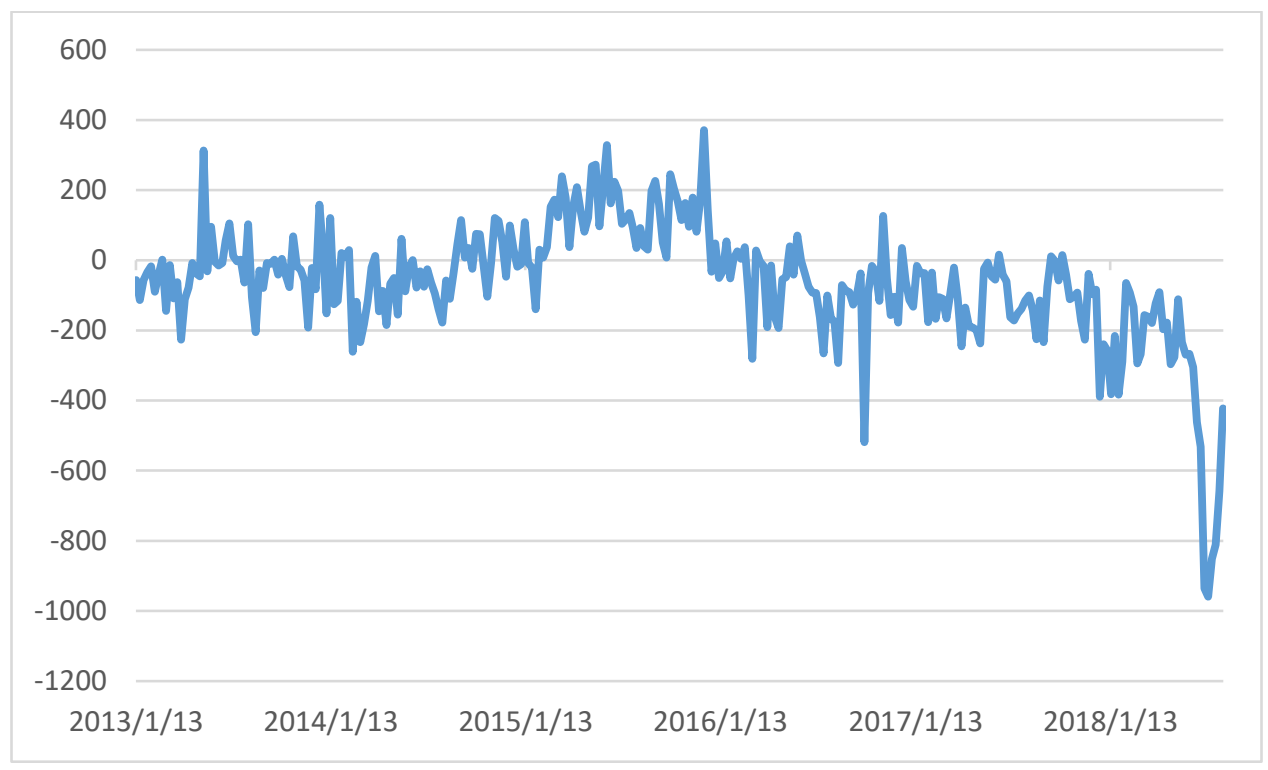

Source: Wang and Huang (2018). 